\title{
Bölcsességfogak koronektómiája és annak szövődményei
}

\author{
Esetismertetés
}

\author{
DR. KÖRMÖCZI KINGA, DR. BOGDÁN SÁNDOR, DR. JOÓB-FANCSALY ÁRPÁD
}

\begin{abstract}
Az alsó impaktált bölcsességfogak sebészi ellátása a beavatkozások buktatói és lehetséges szövődményei miatt komoly kihívást jelenthetnek a szájsebészek, fogorvosok számára. A szövődmények elkerülése érdekében alapos anatómiai, mútéttechnikai ismeretekre, korszerü diagnosztikai módszerekre van szükségünk. Az egyik legrettegettebb szövődmény a nervus alveolaris inferior sérülése, az érintett ajakfél átmeneti vagy maradandó paraesthesiája. Ennek elkerülése érdekében alkalmazható alternatív módszer a bölcsességfogak koronektómiája. Közleményünkben klinikai eseteinken keresztül tekintjük át a koronektómia lehetőségeit, annak lehetséges buktatóit.
\end{abstract}

Kulcsszó: bölcsességfog, szövődmény, koronektómia

\section{Bevezetés}

Az áttörésükben visszamaradt fogak sebészi eltávolítása a fogak sculptiója után a második leggyakrabban végzett beavatkozás a Semmelweis Egyetem Arc-, Állcsont-, Szájsebészeti és Fogászati Klinikáján. Az elmúlt tizenöt évben közel háromszorosára nőtt a retencióban vagy impakcióban lévő fogak eltávolításának száma. Míg 2001-ben 1197 ilyen jellegű beavatkozás történt a klinikán, addig 2016-ban már 3036. Ennek a növekedésnek az egyik leggyakoribb oka, hogy a bölcsességfogak eruptiójuk során fogtorlódáshoz vezethetnek és a fogszabályozó szakorvos kolléga preventív céllal kéri az eltávolításukat. Abban, hogy a frontfogak torlódásának hátterében pontosan mi áll, teljesen biztosak nem lehetünk. Bizonyos irodalmi áttekintések azt írják le, hogy az elő nem törő bölcsességfogak állnak a háttérben, mások pedig cáfolják ezt. Az viszont tény, hogy a helyzeti rendelleneségükből kifolyólag sokszor nehezen tisztíthatók, így az elő nem tört bölcsességfogak körüli nyálkahártya (pericoronitis) vagy maga a fog gyulladásba kerülhet [3, 7].

Az említett beavatkozások több mint felét az alsó, áttörésében visszamaradt bölcsességfogak mútéti eltávolítása teszi ki. Ezek a sokszor magas kockázati aránnyal, szövődménnyel járó mútétek mind a páciens, mind a kezelőorvos számára megterhelők. Talán az egyik legrettegettebb szövődmény a mútét közbeni mechanikai trauma miatt kialakuló idegsérülés. Egy nemrégiben közzétett irodalmi adat szerint - ahol 1200 páciens nervus alveolaris inferior anatómiai lokalizációját vizsgálták - megállapították, hogy az esetek 50\%-ban (férfiaknál 58\%-ban) az alsó bölcsességfo- gak gyökerei közvetlen kapcsolatban vannak a canalis mandibulaeval [11].

Egy 1960-ban végzett tanulmányban a bölcsességfogak mütéti eltávolítása során $8 \%$-ban észleltek ideiglenes, 3,6\%-ban végleges nervus alveolaris inferior sérülést [6].

A Valmaseda-Castellon E és mtsai által 2001-ben végzett vizsgálat szerint az esetek kevesebb mint $1 \%$-ában fordul elő tartós és 0,4-8,4\%-ban reverzibilis nervus lingualis vagy nervus alveolaris inferior károsodás bölcsességfog eltávolítás során [16].

Valószínúleg a korszerúbb diagnosztikai (panorámaröntgen) és mútéttechnikai eljárásoknak, eszközöknek (sebészeti fúró) köszönhető, hogy napjainkban sokkal ritkábban fordul elő intraoperatív idegsérülés, mint korábban. Az idegsérülésekből adódó érzékelészavarok (dysaesthesia, paraesthesia) a páciensek mindennapos tevékenységeit (borotválkozás, beszéd) befolyásolják és életminőségüket nagymértékben rontják. Ez később megjelenhet pszihés, szociális beilleszkedésbeli problémaként, de akár neuropáthiás fájdalom formájában is [12].

A nervus alveolaris inferior sérülés rizikójának számtalan, akár a panoráma-röntgenfelvételen is észlelhető jele van [7, 13, 14]. Ezek a jelek felhívják a figyelmet arra, hogy a gyökércsúcs közel vagy közvetlen kapcsolatban van a canalis mandibulae lefutásával. Az utóbbi évtizedben alkalmazott legkorszerübb diagnosztikai módszer a CBCT (Cone Beam Computed Tomography). A CT-felvételen pontosan megállapíthatjuk a canalis mandibulae lefutását és értékelhetjük a bölcsességfog gyökércsúcsaihoz való pontos viszonyát. Logikusnak tünne, hogy a CBCT-vel történő ter- 
vezés eredményeként csökken a mútéti komplikációk, szövődmények száma [4], de számos publikáció rácáfol erre és nem lát szignifikáns különbséget a panorámaröntgennel, vagy a $\mathrm{CBCT}$-vel történő mütéti tervezés eredménye és a szövődmények előfordulása között. A CT-felvétel nagyon fontos információt nyújt a mútét tervezéséhez, megerősít minket a panorámaröntgenfelvételen is látható ideg-bölcsességfoggyökér viszonyáról, távolságáról. A CBCT-felvételeken bemutathatjuk a páciens számára az állcsonton látható pontos anatómiai viszonyokat, melyek segítségével könynyebben megítélhetjük a mútét esetleges rizikóit, így fontos szerepe van a betegfelvilágosításban és a minőségbiztosításban. A szövődmények kialakulásának valószínúségét a $\mathrm{CBCT}$-felvétel nem csökkenti, mivel a műtétet ugyanolyan gondossággal kell elvégezni, mintha csak panorámafelvételünk lenne [1].

Az alsó bölcsességfogak koronektómiája több mint negyed évszázada alkalmazott módszer, melynek a célja az előbb említett szövődmények előfordulásának minimalizálása. Először Knutsson és mtsai írták le mint alsó impaktált bölcsességfog sebészi eltávolításának alternatíváját [8]. A módszer lényege, hogy a bölcsességfog koronáját a zománc-cement határon fissura fúróval átvágjuk és anélkül, hogy a gyökérrészt kimozdítanánk az alveolusból, a fog koronai részét emelővel „leroppantjuk”, majd eltávolítjuk. A szabadon maradt pulpát nem kezeljük, csak az éles buccalis csontperemet és a zománcrészleteket simítjuk le, majd a szokásos módon zárjuk a sebet. A korona eltávolításával megszüntetjük annak előtörését gátló akadályt, lehetővé téve annak cranialis irányba történő elmozdulását, eruptióját. A műtéti technikát úgy is alkalmazhatjuk, hogy nem a teljes koronát, hanem csak az impakciót okozó részt távolítjuk el. Ezt a múveletek részleges koronektómiájának nevezzük [9]. Ezeket a beavatkozásokat csak jó általános állapotban lévő és jól kooperáló betegeknél szabad elvégezni. A koronektómiát ellenjavallhatja a beteg rossz általános állapota, pulpa-

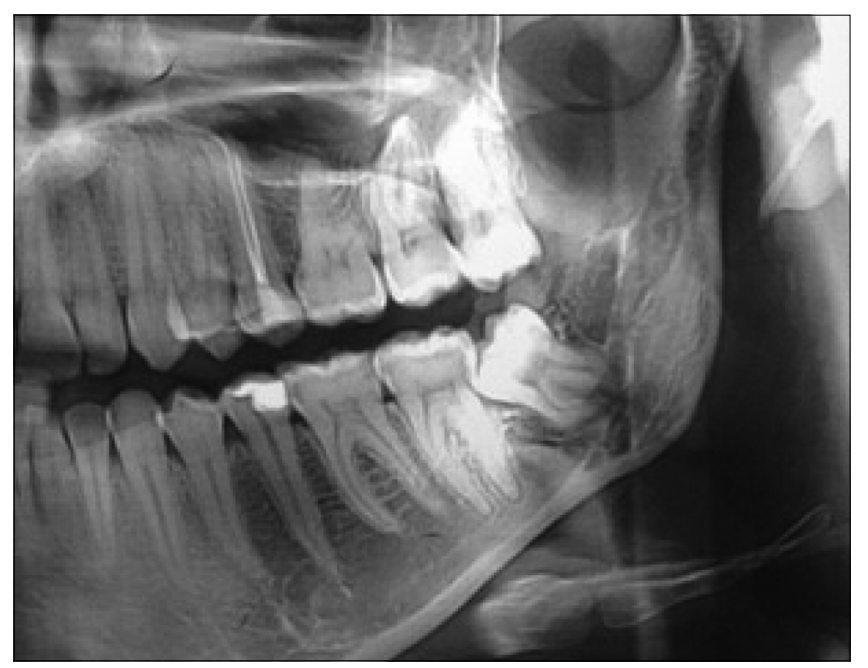

1. kép: Műtét előtti panorámafelvétel necrosis, caries profunda és a bölcsességfog horizontális pozíciója.

A mútét után fontos a páciens szoros radiologiai kontrollja. Háromhavonta érdemes ellenőrizni a megmaradt gyökérrész migrációjának mértékét a canalishoz viszonyítva. Irodalmi adatok alapján az első három posztoperatív hónap alatt a legnagyobb mértékủ a gyökér távolodása a canalis mandibulaetól. Egyes közlemények szerint ebben az időszakban átlagosan $1,9 \mathrm{~mm}$ is lehet a gyökér emelkedése. Egy év elteltével akár $2,97 \mathrm{~mm}$ is lehet ez a távolság az eredeti állapothoz képest. A második évben már nem észlelhető további jelentős változás, migráció [10].

A koronektómiának, mint minden mútéti beavatkozásnak, lehetnek szövődményei, komplikációi. A leggyakoribb szövődmény az alveolitis (5\%), ami nem gyakoribb, mint a bölcsességfog műtéti eltávolítását követően [2]. Ennek kezelése hasonló, mint egy fogeltávolítás után kialakult alveolitis esetében. A tapasztalatok és az irodalmi leírások alapján szintén gyakori szövődmény, ha a koronektómia során zománcrészleteket hagyunk hátra a koronából és felette próbáljuk meg per primam zárni a sebet. Ennek elkerülése érdekében fontos minden esetben postoperavít röntgenfelvétet készíteni. Problémát jelenthet a mútét közbeni gyökér mobilizációja. llyenkor, mivel a periodontális rostok megsérülnek, a parodontális rés kiszélesedhet és gyulladás alakulhat ki. Ennek elkerülése érdekében ilyenkor a fogat érdemes eltávolítani. Viszonylag ritka szövődmény, amikor panaszok miatt egy második beavatkozásra - a gyökér teljes eltávolítására - van szükség. Sebgyógyulási zavarok, állandó fájdalom, pulpanekrózis esetén lehet erre szükség az esetek kevesebb mint 5\%-ában [2].

\section{Első eset}

28 éves nő páciens jelentkezett klinikánkon, bal alsó bölcsességfog eltávolítása céljából. Elmondása szerint az állkapocsszöglet területén időszakonként fellépő feszítő, nyomó fájdalmat érzett. Klinikai vizsgálata során részlegesen előtört bölcsességfogat találtunk, melyet enyhén gyulladt nyálkahártya vett körül. Az elvégzett panorámaröntgen egy mesioangularis pozícióban lévő bölcsességfogat ábrázolt. A fog alatt a canalis mandibulae folytonossága nem volt látható, a gyökerek „kapocsszerűen” összetértek, a mesialis gyökér erősen görbült (1. kép).

A mútéti felvilágosítást követően a páciens - foglalkozását tekintve: színész - nagyon aggódott az idegsérülés következtében esetlegesen kialakuló paraesthesia, anaesthesia miatt. Mivel a koronektómiának nem volt ellenjavallata, ezt a mútéti megoldást választottuk. Helyi érzéstelenítésben, L-alakú metszésből a fog koronai részét a zománc-cement határnál átvágtuk, a koronáját eltávolítottuk, majd a sebet per primam zártuk (2., 3. kép). 


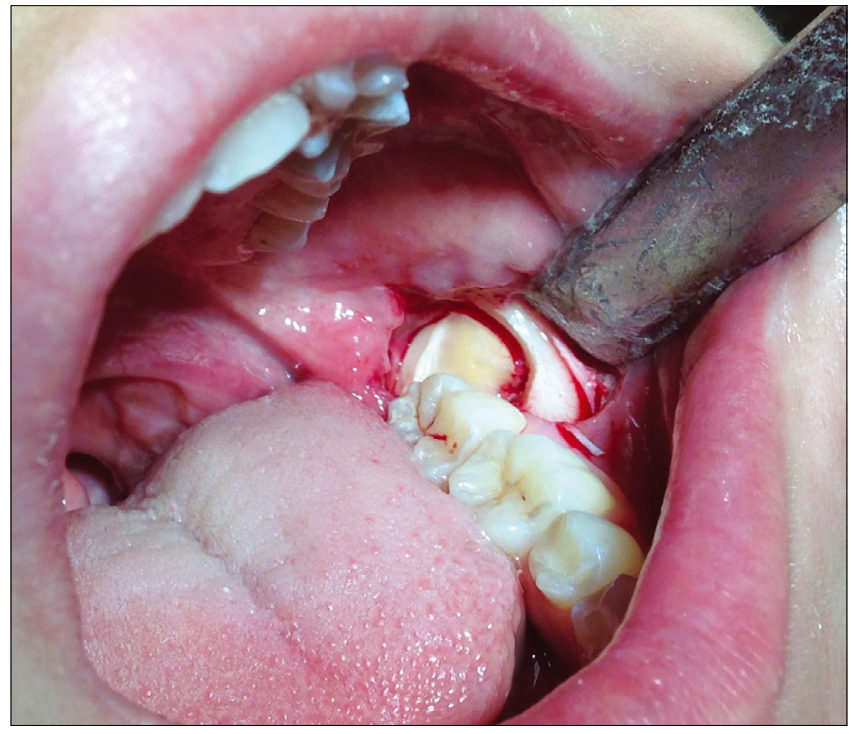

2. kép: A koronai rész eltávolítását követően az idegkamra ép maradt
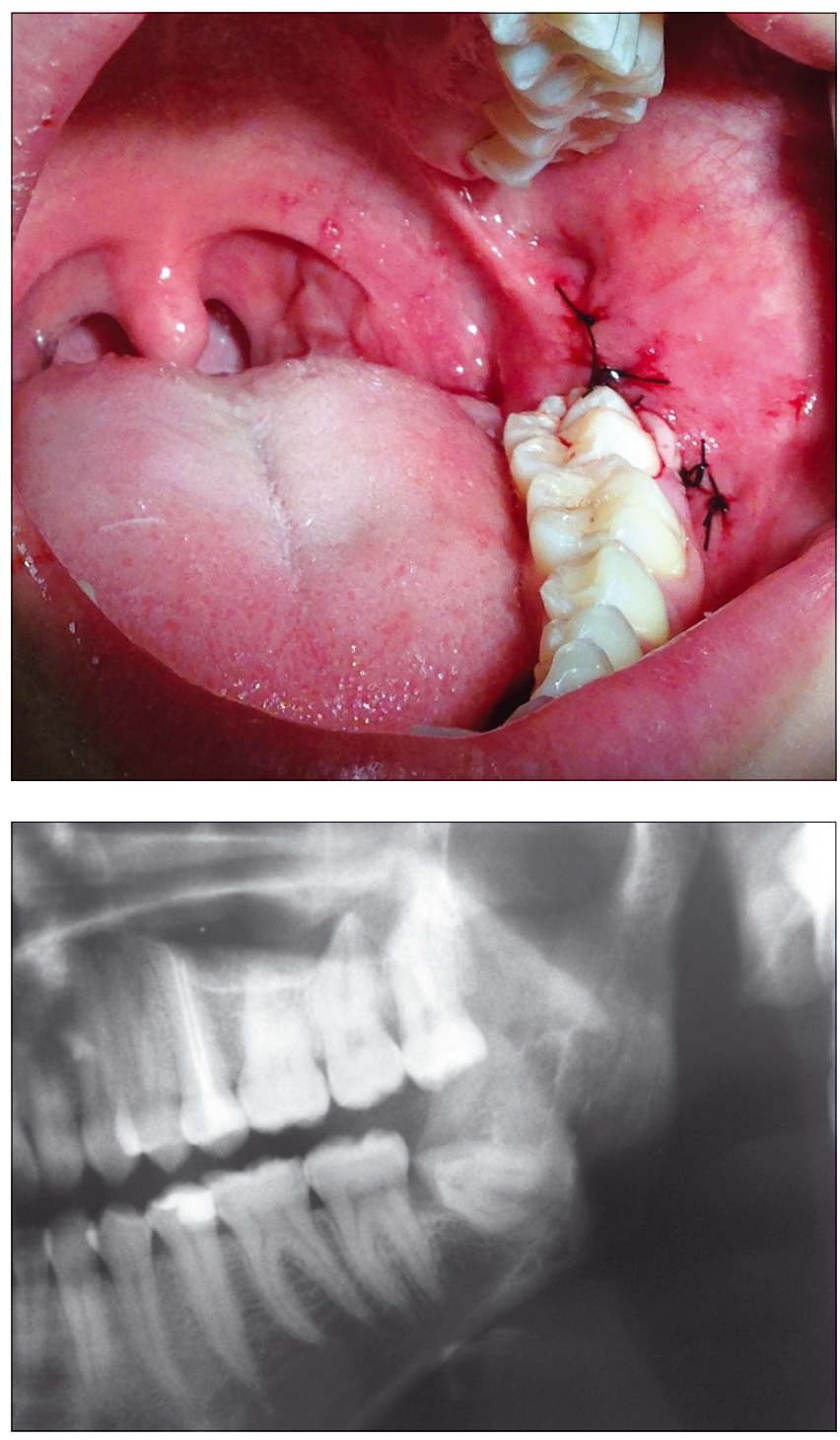

3. kép: Mútétet követő per primam sebzárás és röntgenfelvétel

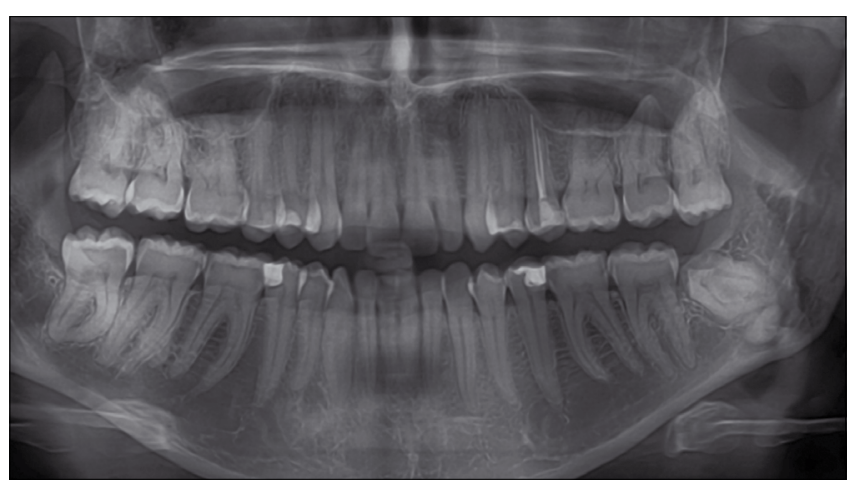

4. kép: 3 éves kontroll panoráma-röntgenfelvétel

Zavartalan, fájdalom és gyulladásmentes sebgyógyulást követően a varratokat egy hét múlva távolítottuk el, illetve kontroll panorámafelvételt készítettünk (3. kép). A mütét 3 éve történt, a kontroll panorámafelvételen megfigyelhető a gyökerek migrációja, illetve új csontképződés a gyökerek felett. A páciens azóta panaszmentes (4. kép).

\section{Második eset}

Klinikánkon 46 éves nőbeteg jelentkezett azzal a panasszal, hogy a 48 fogát nem tudja kellőképpen tisztítani és nagyon sokszor pericoronitis alakul ki körülötte. A magával hozott panorámaröntgen- és CBCT-felvételen egyértelműen ábrázolódott, hogy a foggyökér közvetlenül érintkezik a canalis mandibulaeval (5., 6. kép).

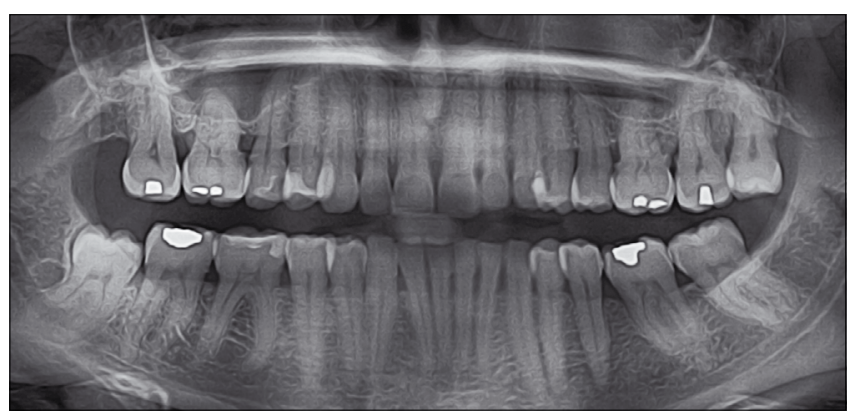

5. kép: Mútét előtti panorámaröntgen

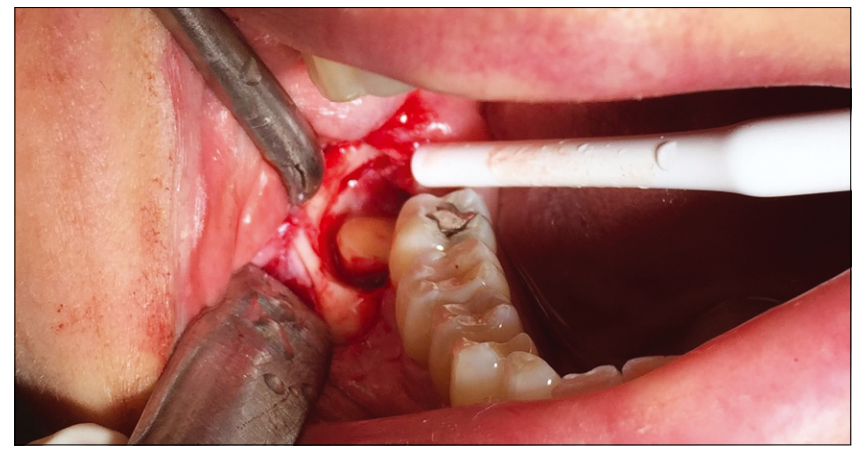

6. kép: Intraoperatív kép a mütéti területről 


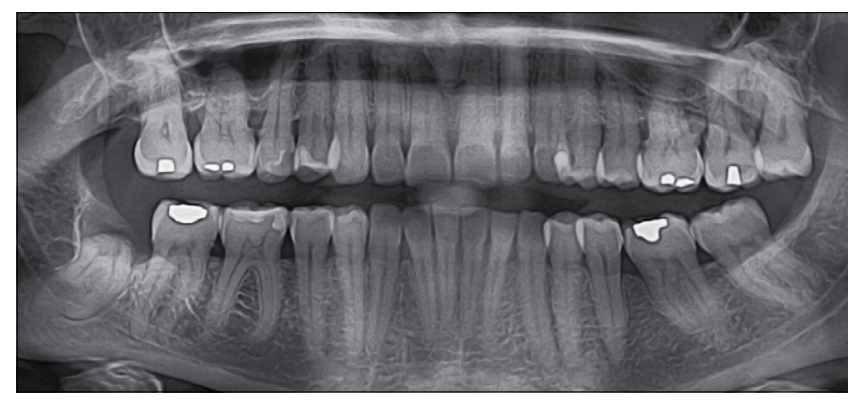

7. kép: Mütét utáni panorámafelvétel

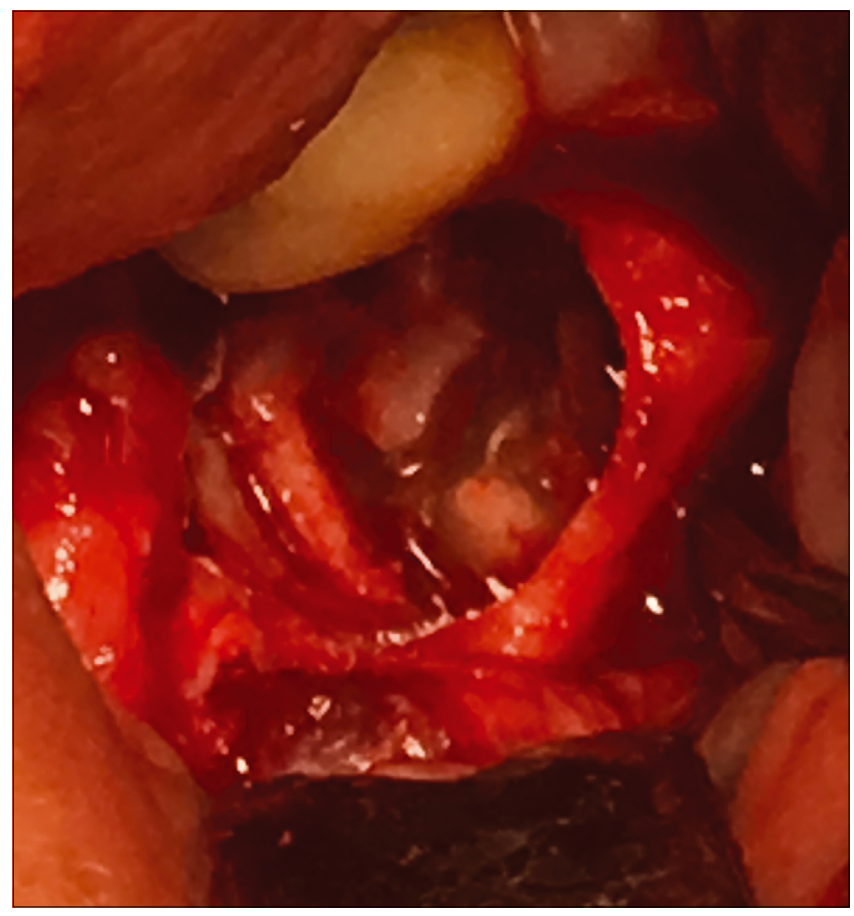

8. kép: Gyökér disszekciója

Mivel a fog pozíciója kedvező volt, a páciens jól kooperált, felajánlottuk a koronektómia lehetőségét. A mütét zavartalanul zajlott, varratszedéskor a beteg kisfokú fájdalomról és paraesthesiáról panaszkodott, mely két héten belül megszűnt (6., 7. kép).

Közel 10 hónapig tartó zavartalan posztoperatív időszakot követően a páciensnél a korábbi mútét területén hirtelen erős fájdalom jelentkezett, mely non-szteroid fájdalomcsillapítók hatására sem szünt meg.

Mivel a panaszok fokozódtak, ezért a fog eltávolítása mellett döntöttünk. Intratrachealis narcosisban a foggyökeret disszekálva, a nervus alveolaris inferiorról óvatosan leválasztva eltávolítottuk a bölcsességfog megmaradt részét (8., 9. kép).

A mútétet követően a páciens fájdalma megszűnt, ugyanakkor féloldali paraesthesia alakult ki az ajak jobb oldalán, mely három hónap múlva teljesen megszünt.

Tekintettel arra, hogy a mútéti területen gyulladásra utaló jelet nem találtunk, és a fájdalom a postoperatív 10 hónapban alakult ki, arra következtettünk, hogy a be-

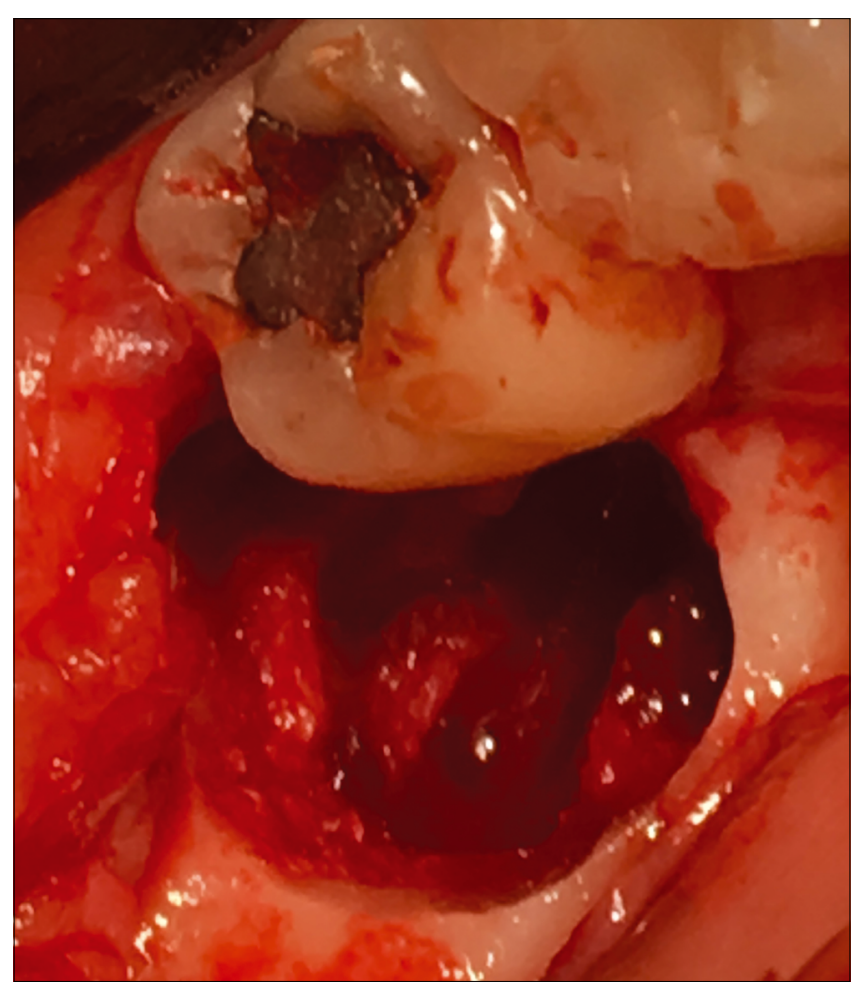

9. kép: Az üres alveolus, benne jól látható az ideg lefutása.

teg erős fájdalmát az idegbe kapaszkodó, időközben elmozduló gyökér által előidézett vongálás okozhatta.

\section{Harmadik eset}

22 éves nő páciens mindkét oldali, alsó bölcsességfogak körül jelentkező, időről időre visszatérő pericoronitis miatt érkezett klinikánkra. Panorámafelvételen a nervus alveolaris inferior a bölcsességfogak gyökereit az alsó egy harmadban keresztezte (10. kép). A látott kép alapján mind a két fog esetében felmerült az intraoperatív idegsérülés lehetősége. A páciens a felvilágosítást követően a részleges koronektómia, majd a gyökerek migrációját követően a fogak teljes eltávolítása mellett döntött.

Mindét oldalon, külön ülésben, helyi érzéstelenítést követően, L-alakú metszésből a Landi és munkatársai által leírt részleges koronektómiának megfelelően csak a fogak mesialis csücskét távolítottuk el keményfém fissurafúró segítségével. A sebet per primam zártuk, a gyógyulási szakasz zavartalan volt (11. kép) [9].

Hat hónappal a koronektómiát követően a pácienst kontrollvizsgálatra hívtuk vissza. A röntgenfelvételen mindkét fog jelentős migrációja, a nervus alveolaris inferiortól való távolodása volt megfigyelhető (12. kép).

A későbbiekben, a páciens annak ellenére, hogy panaszai nem voltak, a fogak teljes eltávolításához ragaszkodott, ezért mindkét bölcsességfogat eltávolítottuk. A mútétet követően a bal oldali fognál megfigyelhető volt, hogy az ideg a két mesialis gyökér között futott, 
a jobb oldal esetén pedig a lingualis oldalon okozott benyomatot (13. kép).

Mindkét mútétet követően a gyógyulási időszak szövődménymentes volt, nem alakult ki egyik oldalon sem paraesthesia.

\section{Összefoglalás}

Az alsó impaktált bölcsességfogak koronektómiája akkor javasolt módszer, amikor a fog vagy annak gyökere közvetlenül érintkezik a canalis mandibulaeval és így a fog eltávolítása fokozott kockázatot rejt az operatör és a páciens számára is. Gyakori, hogy az első mútét után betegeink nem kérik a további beavatkozást, de a koronektómia egyik legfontosabb jelentősége abban rejlik, hogy a mútétet követően a fog eltávolodik a nervus alveolaris inferiortól, és 1 év múlva lényegesen alacsonyabb szövődményrátával távolíthatjuk el. A hazai és külföldi irodalmi adatok alapján egyértelmúen kimondhatjuk, hogy a nervus alveolaris inferior érzéskiesésének lényegesebben kisebb az incidenciája koronektómia esetében, mint a teljes fogeltávolítás során. Ugyanakkor nincs szignifikáns különbség a mütétet követő fájdalomban, az alveolitis kialakulásában és a késői, posztoperatív gyulladások gyakoriságában $[15,17]$.

\section{Irodalom}

1. Aravindaksha sp, balasundaram a, gauthier b, pervolarakis t, boss $\mathrm{H}$, DHAWAN A ET AL: Does the use of Cone Beam CT for the removal of wisdom teeth change the surgical approach compared with panoramic radography? Journal of Oral and Maxillofacial Surgery 2015; 9: 12.

2. Espert JC, martinez SP, ballester JC, oltra DP, diago MP: Coronectomy of impacted mandibular third molars: A meta-analysis and systematic review of the literature. Med Oral Patol Oral Cir Bucal 2016; 21 (4): 505-513.

3. Genest-Beucher S, Graillon N, Bruneau S, Benzaquen M, Guyot L: Does mandibular third molar have an impact on dental mandibular anterior crowding? A literature review. J Stomatol Oral Maxillofac Surg 2018 Mar 20. pii: S2468-7855(18)30072-7. doi: 10.1016/j. jormas.2018.03.005. [Epub ahead of print]

4. Ghaeminia H, meijer GJ, soehardi A, borstlap WA, mulder J, vlijmen OJC ET AL: The use of cone beam CT for the removal of wisdom teeth changes the surgical approach compared with panoramic radiography: a pilot study. Int J Oral Maxillofac Surg 2011; 40 (8): 834-839.

5. Guerrero ME, Botetano R, Beltran J, Horner K, Jacobs R: Can preoperative imaging help to predict postoperative outcome after wisdom tooth removal? A randomized controlled trial using panoramic radiography versus cone-beam CT. Clin Oral Investig 2014; 18 (1): 335-342.

6. Howe GL, Poyton HG: Prevention of damage to the inferior dental nerve during the extraction of mandibular third molars. $\mathrm{Br}$ Dent $J$ 1960; 355-363.

7. Јоо́в FA: A bölcsességfogak szerepe a fogászat különböző szakterületein. Semmelweis Kiadó, Budapest, 2010.

8. KNUTSSON K, LYSELL L, ROHLIN M: Postoperative status after partial removal of mandibular third molar. Swed Dent J 1989; 13 (1-2): 15-22.

9. Landi L, Manicone PF, Piccinelli S, Raia A, Raia R: A novel surgical approach to impacted mandibular third molars to reduce the

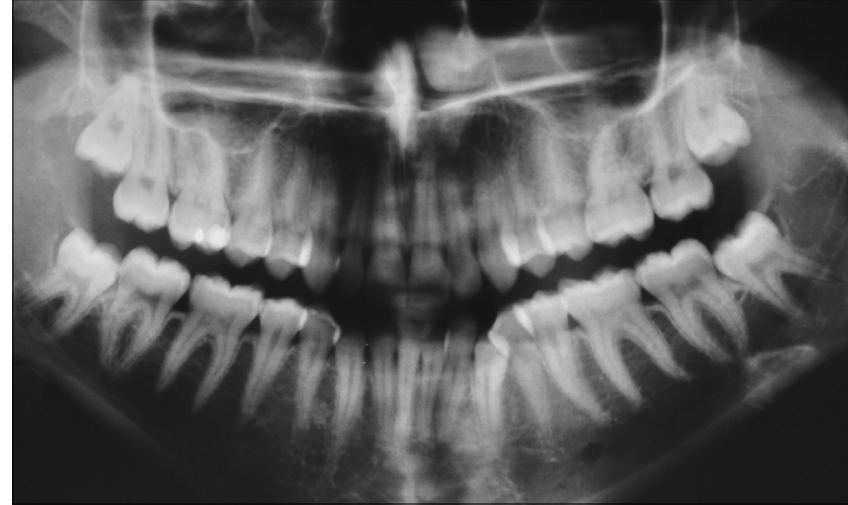

10. kép: Kiindulási panorámafelvétel

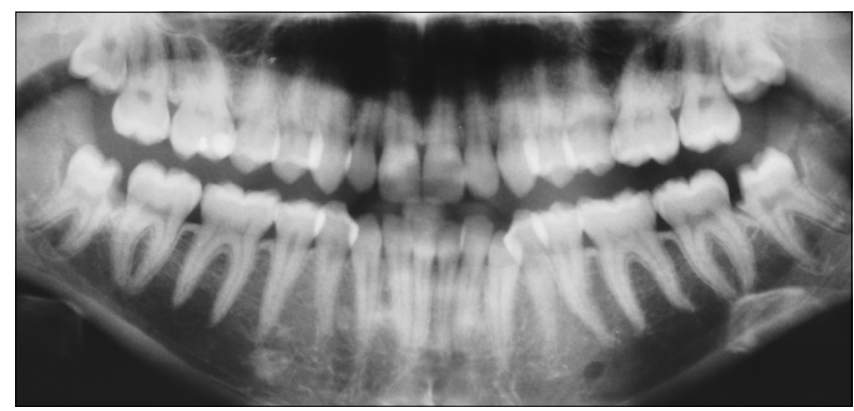

11. kép: Panorámafelvétel közvetlenül a koronektómiát követően

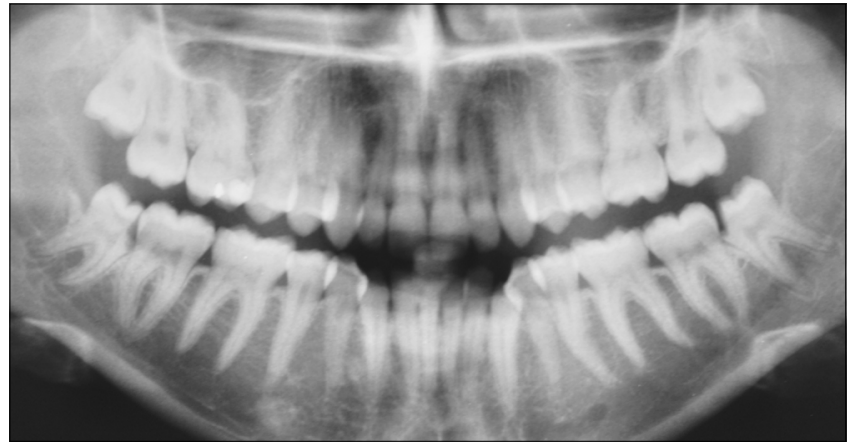

12. kép: 6 hónapos kontroll panorámafelvétel
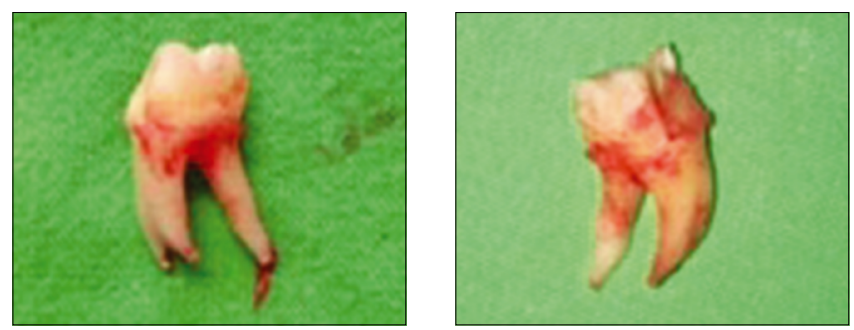

13. kép: Bal és jobb oldali bölcsességfog

risk of paresthesia: a case series. J Oral Maxillofac Surg. 2010; 68 (5): 969-974.

10. LeUNG Y, Cheung LK: Safety of coronectomy versus excision of wisdom teeth: A randomized controlled trial. Oral Surg Oral Med Oral Pathol Oral Radiol Endod 2009; 108 (6): 821-827. 
11. Padhye Mn, Dabir AV, Girotra CS, Pandh VH: Pattern of mandibular third molar impaction in the Indian population: retrospective clinico-radiographic survey. Oral Surg Oral Med Oral Pathol Oral Radiol 2013; 116 (3): 161-166.

12. Sмith JG Eт AL: The psychosocial and affective burden of posttraumatic neuropathy following injuries to the trigeminal nerve. J Orofac Pain 2013; 27 (4): 293-303.

13. Szalma J, Lempel E, Csuta T, Bartfai D, Jeges S, Olasz l: A panorámaröntgen szerepe a nervus alveolaris inferior sérülések várható kockázatában alsó bölcsességfogak eltávolítása előtt. A gyökérgörbület és gyökércsúcs-canalis mandibulae átfedésének hatása a rizikóbecslésre. Fogorv Szle 2010; 43-48.

14. Szalma J, Lempel E, Csuta T, Vajta L, Jeges S, Olasz L: A jellegzetes panorámaröntgen-jelek a nervus alveolaris inferior sérülé- sek várható megítélésében alsó bölcsességfogak eltávolításakor. Fogorv Szle 2011; 27-33.

15. SzaLma J, Lempel E: A nervus alveolaris inferior védelmében: Alsó bölcsességfogak coronectomiája. Irodalmi áttekintés. Orvosi Hetilap 2017; 1787-1793.

16. Valmaseda-Castellon E, Berini-Aytes L, Gay-Escoda C: Inferior alveolar nerve damage after lower third molar surgical extraction: a prospective study of 1117 surgical extractions. Oral Surg Oral Med Oral Pathol Oral Radiol Endod 2001; 92 (4): 377-383.

17. Voegelin TC, Suter VG, Bornstein MM: Complication during and after surgical removal of mandibular third molars. Impact of patient related and anatomical factors. Schweiz Monatschr Zahnmed 2008; 118 (3): 192-198.

\section{KöRMÖcZı K, BogdÁn S, JoóB FÁ}

\section{Wisdom tooth coronectomy and its complications}

The surgical care of the lower impacted wisdom teeth is often a great challenge for oral surgeons and dentists, that may go with a lot of pitfalls and risks as well as complications during surgery. In order to avoid this, careful diagnostic, therapeutic and complication management skills are required. One of the most undesirable complication is the injury of the inferior alveolar nerve. In order to avoid this, we can use coronectomy as an alternative to surgery, instead of completely removing the tooth. This publication describes coronectomy and its complications through case reports.

Keywords: wisdom tooth, complication, coronectomy

\section{Pályázat Körmöczi-pályadíjra}

Felhívjuk minden, a Fogorvosi Szemlében publikáló, rendezett MFE tagsággal rendelkező, 35 évnél fiatalabb első szerzős cikk szerzőjét, hogy pályázzanak a 2018-as Körmöczi-pályadíjra.

Pályázni csak a 2018-ban a Fogorvosi Szemlében megjelent közleményekkel lehet. Kérjük, a közlemény pdf változatát mellékelje a pályázathoz.
A pályázat beadási határideje: 2019. február 4.

A pályázatokat, kérem, emailen juttassák el címemre!

\section{Dr. Fejérdy Pál}

az MFE főtitkára

fejerdy.pal@ dent.semmelweis-univ.hu

\section{Az MFE Fogpótlástani Társaság felhívása}

Az MFE Fogpótlástani Társaság és jogelődje jubileumi fennállásának alkalmából ünnepi anyagot szeretnénk összeállítani.

Kérjük kollégáinkat, hogy aki rendelkezik képanyaggal a Társaság korai időszakából, szíveskedjék elküldeni a demeter.zsofia@dental.unideb.hu címre, vagy a Debreceni Egyetem, Fogorvostudományi Kar, Bioanyagtani és Fogpótlástani Tanszék, 4032 Debrecen, Nagyerdei krt. 98. postacímre!

Köszönettel,

MFE Fogpótlástani Társaság elnökség 